\title{
LIFE SATISFACTION AND HAPPINESS: DISCUSSING THE IMPACT OF FEAR OF CRIME AND VICTIMIZATION ${ }^{1}$
}

\author{
EVA KRULICHOVÁ \\ Institute of Sociology of the Czech Academy of Sciences \\ E-mail: eva.krulichova@soc.cas.cz
}

\begin{abstract}
Subjective well-being is usually studied with respect to marital and occupational status, income or subjective health. Conversely, research examining the relationship between this phenomenon and crime related factors is still relatively limited. This study therefore aims to extent the current knowledge in this area. Using data from the fifth wave of the European Social Survey for the Czech Republic, in which 2386 respondents participated, we conduct a hierarchical regression analysis to find out to what extent victimization experience and fear of crime influence life satisfaction and happiness of Czechs. The results of the analysis reveal a direct relationship between fear of crime and subjective well-being. On the contrary, victimization affects life satisfaction and happiness indirectly via the fear of crime. Surprisingly, a decrease in life satisfaction is greater for fearful men than fearful women, whereas there are no gender differences regarding the fear of crime - happiness link.
\end{abstract}

Key words: fear of crime; victimization; subjective well-being; gender differences; ESS R5

\section{Introduction}

While research on fear of crime usually concentrates on causes of this phenomenon, less attention is paid to its consequences for individuals as well as for the whole society. It may especially be due to the fact that in most cases we operate with a cross-sectional data where identifying causal links is rather questionable. It is, however, confirmed by a number of authors (Garofalo, 1981; Chanley, Rudolph, \& Rahn, 2000; Jackson \& Bradford, 2009; Jackson, Bradford, Hohl, \& Farrall, 2009; Jackson \& Stafford, 2009; Liska, Sanchirico, \& Reed, 1988; Williams, Singh, \& Singh, 1994) that fear of crime can lead to various social problems ranging from lower interpersonal and institutional trust to change in behavioral patterns and lifestyle or worse integration into the society.

Recently, a growing interest has also been paid to the crime related determinants of subjective well-being. This phenomenon is, however, in majority of cases studied with respect to marital and occupational status, income or subjective health (Abdel-Khalek, 2006; Diener, Suh, Lucas, \& Smith, 1999; Hamplová, 2004, 2006, 2015; Stack \& Eshle-

1 This text was funded by the Programme of Support of Perspective Human Resources of the Czech Academy of Sciences and the Ministry of Education, Youth and Sports of the Czech Republic, grant project no. LM2015066. 
man, 1998; Šolcová \& Kebza, 2005) while examination of factors such as victimization experience or fear of crime is limited and predominantly concentrates on western countries (Cohen, 2008; Hanslmaier, 2013; Michalos \& Zumbo, 2000; Staubli, Killias, \& Frey, 2014) or developing and newly industrialized countries of Africa (Davies \& Hinks, 2010; Møller, 2005; Powdthavee, 2005). Moreover, the measurement of well-being is often a subject of debates. Indicators of life satisfaction and happiness as a proxy of subjective well-being are frequently used interchangeably, since both measures seem to be highly correlated and influenced by similar factors (Clark \& Senik, 2011). Nevertheless, the evidence also exists that they present distinct concepts (Diener \& Lucas, 2000; Kim \& Hatfield, 2004; Peiró, 2006) and should be measured separately as two dimensions of subjective well-being.

Using data from the European Social Survey Round 5 (ESS R5) this article therefore examines the association between life satisfaction, happiness, as two separate indicators of subjective well-being, fear of crime and victimization in the Czech Republic.

\section{Defining and measuring subjective well-being, fear of crime and victimization}

Subjective well-being is currently regarded as a multidimensional concept (Diener et al., 1999; Ryan \& Deci, 2001) which reflects the assessment of various areas of human life, whether it is family, work, friends, health, self-esteem, leisure, etc. It is therefore not surprising that to this day no clear and unequivocal concept of what subjective well-being really means has been adopted by the academic community (Hamplová, 2006). According to Deci and Ryan (2001), current research on subjective well-being is derived from two broad perspectives - hedonic and eudaimonic. While the first focuses on happiness and defines subjective well-being in terms of pleasure attainment and pain avoidance, the other emphasizes the role of self-realization and defines well-being as a state when an individual is fully functional. Diener (2000) in turn says that subjective well-being is based on both affective and cognitive evaluations of people's life and defines it as a predominance of positive over negative emotions, engagement in exciting activities that brings pleasure and high life satisfaction.

Research studies focusing on subjective well-being usually ask respondents whether they are generally satisfied with their lives or whether they consider their lives to be happy. According to some authors (Clark \& Senik, 2011), happiness and life satisfaction are strongly correlated. Others argue that while the first is based on individual emotions, the second refers to the cognitive, i.e. rational, evaluation of life (Diener \& Lucas, 2000; Hamplová, 2006; Kim \& Hatfield, 2004). In this article we will therefore deal with the two aforementioned phenomena and their relationship with crime related factors such as victimization and fear of crime.

There is also an ongoing debate about the way of identifying and measuring fear of crime (Ferraro, 1995; Ferraro \& LaGrange, 1987; Moravcová, 2014; Rountree \& Land, 1996). While at the beginning of the research on fear of crime it was measured by a single indicator asking respondents about their feeling of safety in a neighbourhood (Garofalo, 1979; Warr, 2000), Ferraro and LaGrange (1987, p. 72; see also Ferraro 1995, p. 23) de- 
fined fear of crime as "a negative emotional reaction to crime or the symbols associated with crime" and came with so called "emotional" indicators asking explicitly about fear of wide range of criminal offences. This approach is favourable, however, problematic with respect to a limited extent of questionnaires and questions that can be posed to respondents. Since this study uses data from an international research which, in addition to fear of crime, is also focused on other social issues, fear of crime is measured by only two indicators that ask respondents if they fear of their home being burgled and becoming a victim of violent crime.

Problems concerning operationalization of victimization experience and identification of victims can also be observed (Agnew, 1985). For example, victimization surveys usually concentrate solely on recent victimization (in the last 2 or 5 years) and thus people who have been victimized many years ago are classified as non-victims. Some authors (e.g. Pain, 1995), however, argue that certain social groups (especially women and seniors) can be affected by victimization for a relatively long time. In this study the victimization indicator asks respondents if they or a member of their household have been a victim of burglary or assault (which corresponds with questions on fear of crime) in the last 5 years.

\section{Who is happy and satisfied?}

Life satisfaction and happiness are most often associated with marital and occupational status, income or subjective health. Evidence exists that those, who are married, have a good and stable job, a sufficient amount of money and feel healthy, declare higher level of life satisfaction and happiness than those who live alone without partner, are unemployed, lack of finances or suffer from some disease (Diener et al., 1999; Hamplová, 2004, 2006, 2015; Stack \& Eshleman, 1998; Zimmermann \& Easterlin, 2006).

With respect to marital status, it is argued that married people benefit from a close relationship with their partners who provide them with emotional support and protection. They are also considered healthier, because they encourage each other to take care of themselves and wealthier, because they manage their finances together (Stack \& Eshleman, 1998). Although it might seem that one of the factors leading to greater life satisfaction and happiness is money, the relationship between mentioned phenomena is more complex (Ahuvia, 2008; Becchetti \& Rossetti, 2009; Blanchflower \& Oswald, 2004; Diener \& Oishi, 2000; Easterlin, 2001). For example, Ahuvia (2008) points to the fact that once basic needs are met, the effect of income on happiness significantly weakens. Moreover, Ferrer-i-Carbonell (2005) finds out that income of a reference group is about as important as the own income. He confirms that higher the individual's income is in comparison with the income of the reference group the happier the individual is. On the other hand, if there is an increase in both own and reference group's income, the changes in happiness are almost negligible. Given a relatively weak effect of income on well-being, the role of unemployment is often discussed. According to a number of studies (Frey \& Stutzer, 2002a, 2002b; Winkelmann \& Winkelmann, 1998) those who are employed declare higher life satisfaction and happiness than those who have lost their job and this relationship remains stable even though the level of income is controlled for. On the 
contrary, women on maternity leave or housewives are found to be as happy and satisfied as those with a job (Beja, 2014). According to Abdel-Khalek (2006), however, the main factor influencing happiness is mental health (while physical health has no effect). In line with this finding, Diener et al. (1999) point to the fact that subjective well-being is rather dependent on individual perception (assessment) of illness and ability to cope with it. Someone who is severely ill can thus adapt to his condition and live a satisfied life whereas someone else, whose condition is not so serious but fail to adapt to it, can declare to be unhappy and dissatisfied.

\section{The effect of fear of crime and victimization}

As already mentioned, the research focusing on the relationship between life satisfaction, happiness and crime related phenomena such as victimization or fear of crime is relatively scarce and its findings are often mixed. With respect to victimization experience, Hanslmaier (2013) points to the significant effect of victimization on life satisfaction. Staubli, Killias, and Frey (2014) examine the influence of various types of victimization on life satisfaction and conclude that there is a negative association between life satisfaction and crimes against property such as theft, burglary, consumer fraud as well as crimes against person such as assault, threat, robbery or sexual offences (Møller, 2005; Powdthavee, 2005). Cohen (2008) finds a relatively strong relationship between fear of crime and subjective well-being only with respect to burglary while robbery remains nonsignificant. On the contrary, Michalos and Zumbo (2000) find some support for victimization - life satisfaction, happiness and quality of life link only in the bivariate analysis, while in the multivariate regression, where measures of satisfaction with family life, health, self-esteem etc. were added, it reveals to be nonsignificant. Similarly, Moore (2006) reports no effect of victimization on happiness; however, fear of crime decreases it significantly. According to Hanslmaier (2013) victimization could influence happiness vicariously right through the fear of crime. Nevertheless, his data show a direct effect of both victimization and fear of crime on life satisfaction. In turn Adams and Serpe (2000) found that fear of crime affects life satisfaction indirectly through decreasing people's sense of control over their lives.

Further, gender differences in the fear of crime - subjective well-being link have not been examined in depth. We are not aware of any study which would discuss different impact of fear of crime on life satisfaction and happiness among women and men in Europe. The only study which partly deals with such gender differences is the one by Davies and Hinks (2010) who analyze data from Malawi. Authors find out that for men both victimization and feeling unsafe negatively affect life satisfaction while for women only feeling unsafe plays an important role. In line with these results and with respect to a higher level of fear of crime among women (see below) and the fact that both fear of crime and subjective well-being are considered to be largely based on emotions, we would expect that among women fear of crime could enhance dissatisfaction and unhappiness to a greater extent than among men. Therefore an interaction term between fear of crime and gender is also examined in the subsequent analysis. 


\section{Correlates of fear of crime}

The relationship between fear of crime and victimization has been confirmed by a number of studies (e.g. Andreescu, 2010; Hanslmaier, 2013; Skogan \& Maxfield, 1981; Tseloni \& Zarafonitou, 2008). The results of such studies suggest that people who became victims of crime or those who were victimized indirectly by knowing someone (friends, relatives, colleagues, neighbours etc.) who experienced victimization fear crime to a greater extent than those who have never came into contact with crime. Some authors (Ferraro, 1995; Garofalo, 1979; Liska et al., 1988; Pechačová, Hraba, Bao, \& Lorenz, 1998; Wanner \& Caputo, 1987), however, find only weak, negative or no association between these phenomena. Since there exists a discrepancy between fear of crime and victimization, fears of certain social groups were labelled as "paradoxical". For example, women are consistently found to declare greater fear of crime than men (Box, Hale, \& Andrews, 1988; Jackson \& Stafford, 2009; LaGrange \& Ferraro, 1989; Russo, Roccato, \& Vieno, 2013; Tseloni \& Zarafonitou, 2008) although it is the men who are, according to official police statistics, more frequently victimized (Hale, 1996). It is assumed that women are in general more vulnerable to crime and sensitive to potential risk of victimization. This vulnerability or sensitivity is likely to origin in the process of socialization during which women are learned to be fearful and take care while men are encouraged to be brave and take risk (Garofalo, 1979; Sacco, 1990). With respect to age and education the evidence is, however, mixed. While some studies indicate older and educated people to be more fearful (Box et al., 1988; Gainey, Alper, \& Chappell, 2011; Jackson \& Stafford, 2009; Pechačová et al., 1998; Smith \& Hill, 1991b; Tuček, 2013; Warr, 1984; Yin, 1980), other declare higher levels of fear among youths and those with lower education (Ferraro \& LaGrange, 1992; Chadee \& Ditton, 2003; Jackson, 2009; LaGrange \& Ferraro, 1989; Smith \& Hill, 1991a; Weinrath \& Gartrell, 1996). It also turns out that fear of crime is not linked solely to characteristics of individuals but also to the environment, in which they live and people that surround them. According to Lewis and Salem (1986) or Skogan and Maxfield (1981) it is higher level of physical (vandalism, abandoned cars and buildings, graffiti or litters) and social (rowdy neighbours, homeless and drunks, unsupervised youths) disorganization which increases fear of crime among residents of a certain area (cf. LaGrange, Ferraro, \& Supancic, 1992). This is also the reason why fear of crime is primarily and constantly associated with large cities and agglomerations, while in rural areas people feel safe and usually declare minimal fear of crime (Sacco, 1985).

\section{Research hypotheses and analytic strategy}

The current study attempts to analyse the relationship between life satisfaction, happiness, fear of crime and victimization. This area of research remains relatively unexplored given the fact that subjective well-being is perceived to be predominantly influenced by other factors, such as marital and occupational status, income or subjective health condition. First, this study explores the relationship between fear of crime and victimization while controlling for gender, age, education and place of residence. Second it concen- 
trates on life satisfaction and happiness and its association with mentioned crime related phenomena. We use a hierarchical regression analysis to test our hypotheses.

Hypothesis 1: Those who became victims of crime fear crime to a greater extent than those who have no victimization experience. Moreover, it is women and those living in bigger cities that fear crime more than men and those living in smaller cities or countryside.

Hypothesis 2: Fear of crime is associated with dissatisfaction with life and unhappiness. Individual victimization experience influence well-being indicators indirectly right through the fear of crime.

Hypothesis 3: The effect of fear of crime on subjective well-being is greater among women, i.e. the relationship between fear of crime, life satisfaction and happiness is gender specific.

Hypothesis 4: The relationship between indicators of well-being and fear of crime remains significant although variables such as marital and occupational status or subjective health are controlled for.

\section{Data}

The study is based on data of the European Social Survey Round 5 (ESS R5) ${ }^{2}$ which contains indicators measuring subjective well-being as well as victimization experience and fear of crime. In the Czech Republic, the data were collected at the beginning of 2011 by multistage stratified random sampling and total of 2386 respondents took part in the survey. During the analysis, we use a weight (d-weight) to correct for unequal selection probabilities of the individuals in analyzed countries. The ESS R5 is a part of an on-going European Social Survey (ESS) project in which approximately 30 countries currently participate. This biennial international survey was first conducted in $2002 / 2003$. Its goal is to provide long-term comparative research that meets the highest methodological standards and provides information on values, attitudes, behaviour, socio-demographic and sociostructural characteristics of European nations (Jowell et al., 2007).

\section{Measures}

Table 1 presents variables included in the analysis. There are two indicators of subjective well-being - life satisfaction and happiness (All things considered, how satisfied are you with your life as a whole nowadays?; Taking all things together, how happy would you say you are?). Both variables are measured on a 11-item scale ranging from extremely dissatisfied / unhappy (coded ' 0 ') to extremely satisfied / happy (coded '10').

Fear of crime is measured as a mean of two items asking respondents on a 4 -item scale, ranging from ' 1 ' = all or most of the time to ' 4 ' = never, how often they worry about being burgled or becoming a victim of violent crime (How often, if at all, do you worry about your home being burgled?; How often, if at all, do you worry about becoming a victim of

2 ESS Round 5: European Social Survey Round 5 Data (2010). Data file edition 3.2. Norwegian Social Science Data Services, Norway - Data Archive and distributor of ESS data for ESS ERIC. 
Table 1: Descriptive statistics and associations between variables

\begin{tabular}{|c|c|c|c|c|c|c|}
\hline & Mor $(\mathrm{CD})$ & 0 & Darct & & Effect size & \\
\hline & ivean (JD) & 10 & Nange & (A) & (B) & (C) \\
\hline (A) Life satisfaction & $6.41(2.18)$ & & $0-10$ & & & \\
\hline (B) Happiness & $6.70(1.91)$ & & $0-10$ & $0.72^{* * *}$ & & \\
\hline (C) Fear of crime ${ }^{a}$ & $1.27(0.23)$ & & $1-2$ & $-0.15^{\star * *}$ & $-0.15^{\star * *}$ & \\
\hline Victimization $(1=$ yes $)$ & $0.12(0.32)$ & & $0-1$ & $-0.21^{* * *}$ & $-0.20^{* * *}$ & $0.79^{* * *}$ \\
\hline Gender $(1=$ male $)$ & $0.51(0.50)$ & & $0-1$ & 0.05 & 0.06 & $-0.38^{* * *}$ \\
\hline Age & $44.01(17.20)$ & & $15-92$ & $-0.14^{\star * *}$ & $-0.17^{* * *}$ & $0.10^{* * *}$ \\
\hline Education & & & $1-4$ & $0.16^{* * *}$ & $0.15^{\star * *}$ & 0.06 \\
\hline primary & & 14.6 & & & & \\
\hline secondary (lower) & & 40.1 & & & & \\
\hline secondary (upper) & & 34.5 & & & & \\
\hline tertiary & & 10.8 & & & & \\
\hline Residence & & & $1-3$ & 0.04 & $0.06^{*}$ & $0.10^{* * *}$ \\
\hline big city, suburbs & & 31.5 & & & & \\
\hline medium, small city & & 40.9 & & & & \\
\hline countryside & & 27.6 & & & & \\
\hline Marital status & & & $1-3$ & 0.02 & 0.03 & $0.06^{*}$ \\
\hline married & & 50.8 & & & & \\
\hline unmarried with partner & & 7.9 & & & & \\
\hline unmarried without partner & & 41.3 & & & & \\
\hline Occupational status & & & $1-5$ & $0.19^{\star * *}$ & $0.23^{\star * *}$ & $0.09^{* *}$ \\
\hline employed & & 54.7 & & & & \\
\hline unemployed & & 6.3 & & & & \\
\hline retired & & 21.1 & & & & \\
\hline housework & & 4.9 & & & & \\
\hline student & & 13.0 & & & & \\
\hline Subjective health & & & $1-3$ & $0.34^{* * *}$ & $0.33^{* * *}$ & $0.19^{* * *}$ \\
\hline good & & 63.5 & & & & \\
\hline fair & & 26.2 & & & & \\
\hline bad & & 10.4 & & & & \\
\hline
\end{tabular}

${ }^{a}$ Fear of crime square rooted

${ }^{\mathrm{b}}$ Effect size evaluated by Pearson's $r$ (scale variables), Cohen's d (binary factors) - statistical significance based on $\mathrm{t}$-test, or Eta (factors with multiple levels) - statistical significance based on $\mathrm{F}$ test.

${ }^{* * *} \mathrm{p}<0.001,{ }^{* *} \mathrm{p}<0.01,{ }^{*} \mathrm{p}<0.05$

Source: ESS R5 
violent crime?). For the sake of easier interpretation, the final scale was inverted so that ' 4 ' $=$ all or most of the time. To assess victimization experience the respondents were asked if they or any member of their household became a victim of burglary or assault in the last five years (Have you or a member of your household been the victim of a burglary or assault in the last 5 years?). This binary variable is coded as ' 1 ' $=$ yes and ' 0 ' $=$ no.

Given that marital and occupational status as well as subjective health are perceived as strong correlates of personal well-being, we test the significance of life satisfaction, happiness and fear of crime relationship while including the mentioned variables in the analysis. Marital status is a combination of two questions measuring formal marital status and the fact that an individual currently lives with a partner. Three categories are created: ' 1 ' = married, ' 2 ' = unmarried with partner, ' 3 ' = unmarried without partner. Rather than income, which proved to be a relatively weak predictor of subjective well-being, we control for occupational status of an individual with answer categories ' 1 ' = employed, ' 2 ' = unemployed, ' 3 ' = retired, ' 4 ' = housework, ' 5 ' = student. Finally, subjective health (How is your health in general?) is measured on 5-item scale with answer categories ' 1 ' = very good, ' 2 ' = good, ' 3 ' = fair, ' 4 ' = bad and ' 5 ' = very bad. For the sake of the regression analysis we recoded the variable into three categories so that answers "very good" and "good" were merged to "good" (coded as ' 1 ') and "very bad" and "bad" to "bad" (coded as ' 3 ').

As control variables we include gender, age, education and place of residence. Gender is a binary variable where ' 1 ' = male and ' 0 ' = female. Age is measured as a scale ranging from 15 to 92 years. Education is divided into four categories - primary, lower secondary (vocational training, apprenticeship), upper secondary (grammar school) and tertiary (university). Place of residence is relevant especially with respect to fear of crime as the level of social disorganization, which is usually associated with large cities and agglomerations, plays an important role in influencing individual fear of potential victimization. Since the ESS R5 does not include indicators on social disorganization, we decided to, at least, distinguish between different areas where respondents live, i.e. ' 1 ' = big city, suburbs, ' 2 ' = medium, small city, ' 3 ' = countryside.

\section{Results}

Table 1 shows descriptive statistics and results of the bivariate analysis. As expected victimization experience plays an important role in explaining fear of crime. Those who became victims of crime fear crime more than their counterparts. Further, women and those who live in bigger cities and agglomerations fear more than men and those living in the countryside. The relationship between indicators of subjective well-being and fear of crime is statistically significant. Those who fear crime are less satisfied and happy than those whose fear of crime is relatively low. The strength of the relationship is, however, rather weak. Surprisingly, the bivariate analysis shows no association between our dependent variables (life satisfaction and happiness) and marital status. This is, however, due to the fact that there are also widowed or divorced among "unmarried" and we do not control for the age of a respondent at this stage of analysis. The significant relationship between the mentioned variables thus reveals in the subsequent regression analysis. On the other hand, we find a moderate relationship between subjective well-being, occupa- 
tional status and subjective health. Unemployed and those who assess their health as bad declare to be less satisfied and happy than their counterparts. Bad subjective health is also associated with higher fear of crime, the strength of the relationship is, however, rather weak. Finally, both indicators of subjective well-being are mutually correlated (Pearson $=0.72$ ).

Factors influencing the level of fear of crime are showed in Table 2. Victimization experience relevels to be a strong predictor of fear of crime $(\beta=0.245)$ even though we control for respondent's gender, age, education and place of residence. By entering victimization in Model 2, the adjusted $\mathrm{R}^{2}$ increases about 6 percentage points. Victims of crime declare substantially higher fear of crime than those without any criminal experience. Furthermore, comparing to their counterparts, fear of crime is characteristic for women and residents of bigger cities as well as for older people. On the other hand, education turns out to be nonsignificant. Based on these findings, which are in accordance with a number of studies exploring fear of crime and its correlates (e.g. Andreescu, 2010; Hanslmaier, 2013; Jackson, 2009; Russo, Roccato, \& Vieno, 2013; Tseloni \& Zarafonitou, 2008 etc.), we can corroborate the Hypothesis 1.

Table 2: Hierarchical OLS regression for fear of crime

\begin{tabular}{|c|c|c|c|c|c|c|}
\hline & \multicolumn{3}{|c|}{ Model 1} & \multicolumn{3}{|c|}{ Model 2} \\
\hline Variable & b & & $\beta$ & b & & $\beta$ \\
\hline Constant & 1.216 & $* * *$ & & 1.202 & $* * *$ & \\
\hline Gender $(1=$ men $)$ & -0.084 & $* * *$ & -0.182 & -0.088 & $* * *$ & -0.190 \\
\hline Age & 0.001 & $* * *$ & 0.095 & 0.001 & $* * *$ & 0.100 \\
\hline \multicolumn{7}{|l|}{ Education (ref. primary) } \\
\hline secondary (lower) & 0.011 & & 0.023 & 0.010 & & 0.022 \\
\hline secondary (upper) & 0.023 & & 0.048 & 0.021 & & 0.044 \\
\hline tertiary & 0.024 & & 0.033 & 0.017 & & 0.023 \\
\hline \multicolumn{7}{|c|}{ Residence (ref. countryside) } \\
\hline big city. suburbs & 0.059 & $* * *$ & 0.119 & 0.042 & $* * *$ & 0.085 \\
\hline medium. small city & 0.024 & * & 0.051 & 0.023 & * & 0.050 \\
\hline Victimization ( $1=$ yes $)$ & & & & 0.176 & $* * *$ & 0.245 \\
\hline Adjusted $R^{2}$ & 0.053 & & & 0.111 & & \\
\hline
\end{tabular}

$\mathrm{N}=2305,{ }^{* * *} \mathrm{p}<0.001,{ }^{* *} \mathrm{p}<0.01,{ }^{*} \mathrm{p}<0.05$

Source: ESS R5

Finally, we examine the relationship between well-being indicators, fear of crime and victimization (Table 3). In Model 1 we enter variables influencing fear of crime including victimization (see Table 2). Model 2 adds fear of crime and looks at its unique contribution to explanation of our dependent variables. Last, Model 3 tests significance of fear of crime and interaction term between fear of crime and gender, while taking into consideration marital and occupational status and subjective health. 
Gender, age, education, place of residence and victimization influence life satisfaction and happiness in a similar way (Model 1). While there is no effect of gender, younger and educated people as well as those living in smaller cities and countryside are significantly more satisfied and happier than seniors, people with lower education and residents of big cities and suburbs. Moreover, there is a negative, although relatively weak, relationship between subjective well-being and victimization. Those who became victims of crime (whether directly or indirectly) declare lower levels of life satisfaction and happiness than those who have not been victimized.

Further, we test the relationship between subjective well-being and fear of crime (Model 2). Although the adjusted R2 suggests that fear of crime explains only a small part of variance of our dependent variables, the relationship is statistically significant and shows that those who fear crime are less satisfied $(\beta=-0.137)$ and happy $(\beta=-0.130)$ than those whose fears are at low levels. When controlling the fear of crime, victimization turns out to be nonsignificant (Hypothesis 2). This result is in accordance with findings of Moore (2006) who also examines the ESS data. In this regard, Hanslmaier (2013) proposes that victimization could influence life satisfaction indirectly right through the fear of crime (although his data also find a direct effect), which is likely due to the fact that victimization experience is a relatively strong predictor of fear of crime.

In the last model (Model 3) the interaction term between fear of crime and dependent variables is entered as well as factors that are considered to be strongly associated with subjective well-being. Interestingly, the interaction is significant with respect to life satisfaction ( $\beta=-0.274)$ while in the case of happiness it is not. Moreover, its direction differs from our expectations (Hypothesis 3 ) - the effect of fear of crime on decrease in life satisfaction is greater for men. In other words, life satisfaction of fearful men decreases more rapidly than life satisfaction of fearful women. At last, fear of crime remains significant (although relatively weak) correlate of life satisfaction and happiness even though the variables such as marital and occupational status or subjective health are controlled for. We can thus corroborate the Hypothesis 4. As expected, the data show that those who are married are more satisfied and happier than those who live without a partner. Compared to married people, life satisfaction and happiness also slightly decrease for those who do not live within marriage but have a partner. As for occupational status, those who are employed declare higher satisfaction and happiness than those who are unemployed, but lower than those who are retired or study. In the case of life satisfaction, it seems there is no difference between employees and those staying at home, which is in accordance with other research (e.g. Beja, 2014). To conclude, subjective well-being is strongly associated with better health condition - those who feel healthy are more satisfied and happier than their counterparts.

\section{Discussion}

Currently, there is a wide range of studies dealing with subjective well-being and its correlates. Nevertheless, among factors considered in such studies, we can usually find marital and occupational status, income or subjective health. On the other hand, research discussing the relationship between subjective well-being and crime related phenomena 


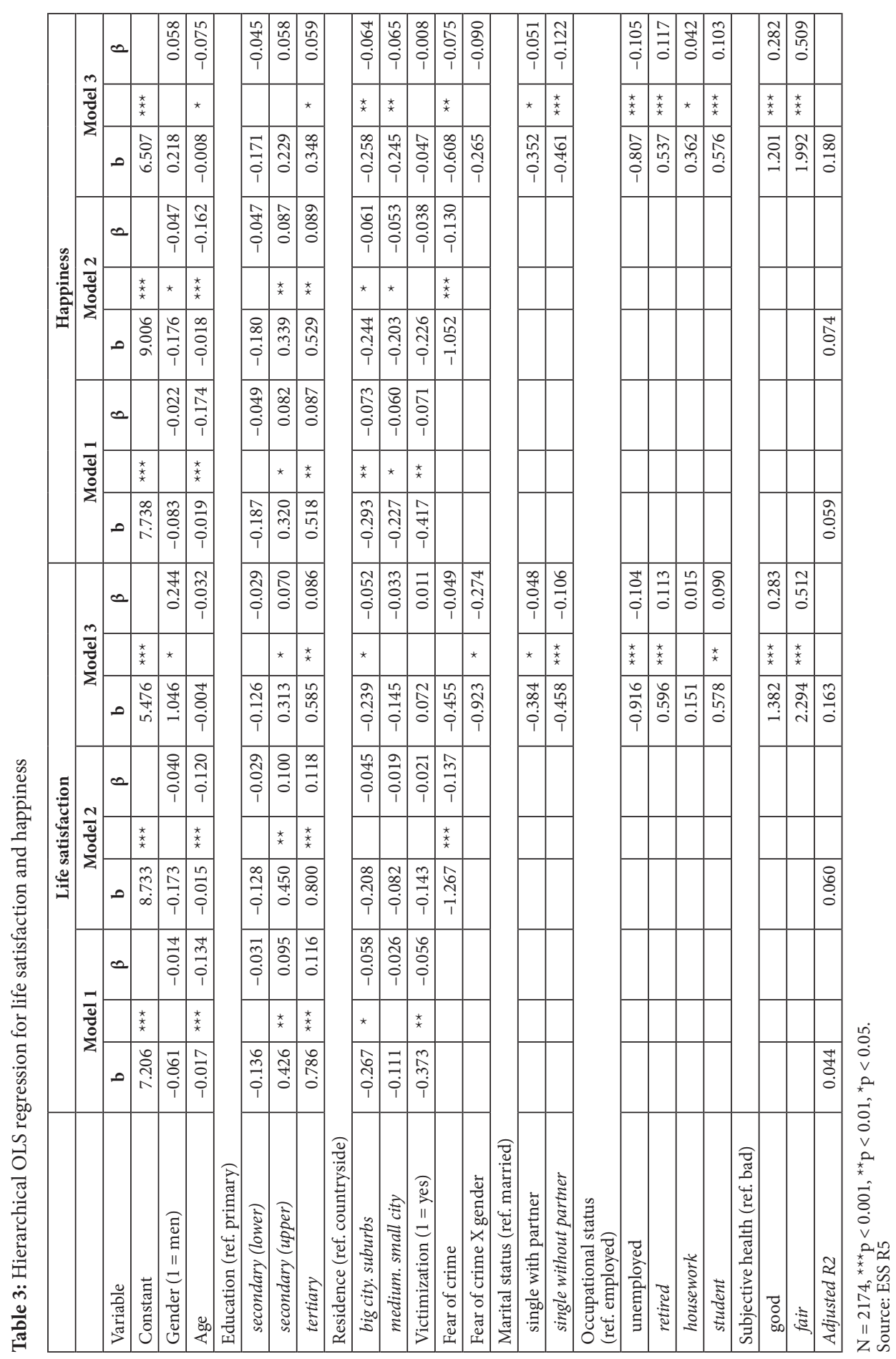


is relatively limited. Hence, the aim of the study was to broaden the knowledge in this regard and find out to what degree the victimization experience and fear of crime contribute to explanation of life satisfaction and happiness among residents of the Czech Republic.

To our knowledge, there are two main limitations in the study. First, subjective wellbeing is measured by two simple indicators asking respondents about their life satisfaction and happiness. These are however considered to be surprisingly valid and reliable measures of mentioned phenomena (Diener \& Lucas, 2000). Next, fear of crime is measured as a mean of two questions focusing on fear of burglary and violent crime (cf. Visser, Scholte, \& Scheepers, 2013) while larger batteries of questions measuring fear of different types of offences would be more appropriate (see Ferraro \& LaGrange, 1992; LaGrange \& Ferraro, 1989). Similarly, and in accordance with the fear of crime measures, victimization indicator only takes into account robbery, burglary and assault. In our opinion, however, it is unlikely that this limitation fundamentally alters the results of our analysis. Second, the cross-sectional nature of the data does not allow us to evaluate causal direction of the analysed relationships. For example, whereas studies mentioned above analyse the influence of victimization and fear of crime on subjective well-being, Andreescu (2010) considers general happiness as one of factors affecting fear of crime. A longitudinal study is therefore needed to test possible causal links between mentioned phenomena.

With respect to victimization, we find it has rather indirect impact on subjective wellbeing. While in the initial regression model the victimization experience decreases life satisfaction and happiness, when controlling for fear of crime, the relationship between victimization and subjective well-being indicators turns out to be nonsignificant. The effect of victimization experience is therefore likely transmitted by fear of crime (cf. Hanslmaier, 2013; Moore, 2006).

Data suggest that fear of crime decreases subjective well-being. Although this relationship is relatively weak, it remains significant even though factors such as marital and occupational status or subjective health are controlled for. Moreover, fear of crime - life satisfaction link seems to be gender specific. The effect of fear of crime on decrease in life satisfaction is greater for men. Conversely, there are no gender differences with respect to happiness. How can we interpret such finding? Since men are constantly less fearful than women, we argue that actual fear of crime may induce greater decrease in their life satisfaction than it would induce among their counterparts. In other words, majority of men does not fear crime, nevertheless, once they do, their life satisfaction significantly lowers, even more than among women. The question remains why there are no gender differences with respect to happiness. Partial explanation for this result could be hidden in the fact that life satisfaction is rather a cognitive-based indicator while the assessment of happiness is, similarly to fear of crime, based on emotions (Diener \& Lucas, 2000). Nevertheless, further research on gender differences in evaluation of life satisfaction and happiness with respect to fear of crime is needed to explore this idea in more depth.

Finally, although there are some differences in factors influencing both dependent variables, the results of our analysis further support the idea of interdependence between life satisfaction and happiness. Those who are satisfied with their lives are likely to be happy and vice versa. Among more satisfied and happier people we can find those who live in a strong marital relationship, have a stable job, enjoy good health as well as those who do not suffer from victimization and are not plagued by fears of crime. 


\section{REFERENCES}

Abdel-Khalek, A. M. (2006). Happiness, health, and religiosity: Significant relations. Mental Health, Religion \& Culture, 9(1), 85-97. http://doi.org/10.1080/13694670500040625

Adams, R. E., \& Serpe, R. T. (2000). Social Integration, Fear of Crime, and Life Satisfaction. Sociological Perspectives, 43(4), 605-629. http://doi.org/10.2307/1389550

Agnew, R. S. (1985). Neutralizing the Impact of Crime. Criminal Justice and Behavior, 12(2), 221-239. http://doi.org/10.1177/0093854885012002005

Ahuvia, A. (2008). If money doesn't make us happy, why do we act as if it does? Journal of Economic Psychology, 29(4), 491-507. http://doi.org/10.1016/j.joep.2007.11.005

Andreescu, V. (2010). Victimization and fear of crime in Romania and Hungary: a comparative analysis. Revista Romana de Sociologie, 21(3-4), 163-183.

Becchetti, L., \& Rossetti, F. (2009). When money does not buy happiness: The case of "frustrated achievers." The Journal of Socio-Economics, 38(1), 159-167. http://doi.org/10.1016/j.socec.2008.08.009

Beja, E. L. (2014). Who is Happier: Housewife or Working Wife? Applied Research in Quality of Life, 9(2), 157-177. http://doi.org/10.1007/s11482-013-9235-9

Blanchflower, D. G., \& Oswald, A. J. (2004). Well-being over time in Britain and the USA. Journal of Public Economics, 88(7), 1359-1386. http://doi.org/10.1016/S0047-2727(02)00168-8

Box, S., Hale, C., \& Andrews, G. (1988). Explaining Fear of Crime. British Journal of Criminology, 28(3), 340-356.

Clark, E., \& Senik, C. (2011). Is Happiness Different From Flourishing? Cross-Country Evidence from the ESS. Revue D'économie Politique, 121(1), 17. http://doi.org/10.3917/redp.211.0017

Cohen, M. A. (2008). The Effect of Crime on Life Satisfaction. The Journal of Legal Studies, 37(S2), 325-353. http://doi.org/10.1086/588220

Davies, S., \& Hinks, T. (2010). Crime and Happiness Amongst Heads of Households in Malawi. Journal of Happiness Studies, 11(4), 457-476. http://doi.org/10.1007/s10902-009-9152-7

Diener, E. (2000). Subjective well-being: The science of happiness and a proposal for a national index. American Psychologist, 55(1), 34-43.

Diener, E., \& Lucas, R. E. (2000). Subjective Emotional Well-being. In M. Lewis \& J. M. Haviland-Jones (Eds.), Handbook of emotions (pp. 325-337). New York: The Guilford Press.

Diener, E., \& Oishi, S. (2000). Money and happiness: Income and subjective well-being across nations. In E. Diener \& E. M. Suh (Eds.), Culture and subjective well-being (pp. 185-218). Springer.

Diener, E., Suh, E. M., Lucas, R. E., \& Smith, H. L. (1999). Subjective well-being: Three decades of progress. Psychological Bulletin, 125(2), 276-302.

Easterlin, R. A. (2001). Income and Happiness: Towards a Unified Theory. The Economic Journal, 111(473), 465-484. http://doi.org/10.1111/1468-0297.00646

Ferraro, K. F. (1995). Fear of Crime: Interpreting Victimization Risk. Albany: State University of New York Press.

Ferraro, K. F., \& LaGrange, R. L. (1987). The Measurement of Fear of Crime. Sociological Inquiry, 57(1), 70-97. http://doi.org/10.1111/j.1475-682X.1987.tb01181.x

Ferraro, K. F., \& LaGrange, R. L. (1992). Are Older People Most Afraid of Crime? Reconsidering Age Differences in Fear of Victimization. Journal of Gerontology, 47(5), 233-244. http://doi.org/10.1093 /geronj/47.5.S233

Ferrer-i-Carbonell, A. (2005). Income and well-being: an empirical analysis of the comparison income effect. Journal of Public Economics, 89(5-6), 997-1019. http://doi.org/10.1016/j.jpubeco.2004.06.003

Frey, B. S., \& Stutzer, A. (2002a). The economics of happiness. World Economics, 3(1), 1-17.

Frey, B. S., \& Stutzer, A. (2002b). What can economists learn from happiness research? Journal of Economic Literature, 40(2), 402-435.

Gainey, R., Alper, M., \& Chappell, A. T. (2011). Fear of Crime Revisited: Examining the Direct and Indirect Effects of Disorder, Risk Perception, and Social Capital. American Journal of Criminal Justice, 36(2), 120-137. http://doi.org/10.1007/s12103-010-9089-8

Garofalo, J. (1979). Victimization and the Fear of Crime. Journal of Research in Crime and Delinquency, 16(1), 80-97. http://doi.org/10.1177/002242787901600107 
Garofalo, J. (1981). The fear of crime: Causes and consequences. Journal of Criminal Law and Criminology, 72(2), 839-857. http://doi.org/10.2307/1143018

Hale, C. (1996). Fear of Crime: A Review of the Literature. International Review of Victimology, 4(2), 79-150. http://doi.org/10.1177/026975809600400201

Hamplová, D. (2004). Životní spokojenost: rodina, práce a další faktory. Sociologické studie (Vol. 04:06). Praha: Sociologický ústav AV ČR.

Hamplová, D. (2006). Životní spokojenost, štěstí a rodinný stav v 21 evropských zemích. Sociologický časopis/Czech Sociological Review, 42(1), 35-55.

Hamplová, D. (2015). Proč potřebujeme rodinu, práci a prátele - Štěstí ze sociologické perspektivy. Praha: Fortuna Libri.

Hanslmaier, M. (2013). Crime, fear and subjective well-being: How victimization and street crime affect fear and life satisfaction. European Journal of Criminology, 10(5), 515-533. http://doi .org/10.1177/1477370812474545

Chadee, D., \& Ditton, J. (2003). Are Older People Most Afraid of Crime? Revisiting Ferraro and LaGrange in Trinidad. British Journal of Criminology, 43(2), 417-433. http://doi.org/10.1093/bjc/43.2.417

Chanley, V. A., Rudolph, T. J., \& Rahn, W. M. (2000). The Origins and Consequences of Public Trust in Government. Public Opinion Quarterly, 64(3), 239-256. http://doi.org/10.1086/317987

Jackson, J. (2009). A psychological perspective on vulnerability in the fear of crime. Psychology, Crime \& Law, 15(4), 365-390. http://doi.org/10.1080/10683160802275797

Jackson, J., \& Bradford, B. (2009). Crime, policing and social order: on the expressive nature of public confidence in policing. The British Journal of Sociology, 60(3), 493-521. http://doi.org/10.1111/j.1468 $-4446.2009 .01253 . x$

Jackson, J., Bradford, B., Hohl, K., \& Farrall, S. (2009). Does the Fear of Crime Erode Public Confidence in Policing? Policing, 3(1), 100-111. http://doi.org/10.1093/police/pan079

Jackson, J., \& Stafford, M. (2009). Public Health and Fear of Crime: A Prospective Cohort Study. British Journal of Criminology, 49(6), 832-847. http://doi.org/10.1093/bjc/azp033

Kim, J., \& Hatfield, E. (2004). Love Types And Subjective Well-Being: A Cross-Cultural Study. Social Behavior and Personality: An International Journal, 32(2), 173-182. http://doi.org/10.2224 /sbp.2004.32.2.173

LaGrange, R. L., \& Ferraro, K. F. (1989). Assessing Age and Gender Differences in Perceived Risk and Fear of Crime. Criminology, 27(4), 697-719. http://doi.org/10.1111/j.1745-9125.1989.tb01051.x

LaGrange, R. L., Ferraro, K. F., \& Supancic, M. (1992). Perceived Risk and Fear of Crime: Role of Social and Physical Incivilities. Journal of Research in Crime and Delinquency, 29(3), 311-334. http://doi .org/10.1177/0022427892029003004

Lewis, D. A., \& Salem, G. (1986). Fear of crime: Incivility and the production of a social problem. New Brunswick, New Jersey: Transaction Publishers.

Liska, A. E., Sanchirico, A., \& Reed, M. D. (1988). Fear of Crime and Constrained Behavior Specifying and Estimating a Reciprocal Effects Model. Social Forces, 66(3), 827-837. http://doi.org/10.1093 $/$ sf/66.3.827

Michalos, A. C., \& Zumbo, B. D. (2000). Criminal Victimization and the Quality of Life. Social Indicators Research, 50(3), 245-295. http://doi.org/10.1023/A:1006930019814

Møller, V. (2005). Resilient or Resigned? Criminal Victimisation and Quality of Life in South Africa. Social Indicators Research, 72(3), 263-317. http://doi.org/10.1007/s11205-004-5584-y

Moore, S. C. (2006). The value of reducing fear: an analysis using the European Social Survey. Applied Economics, 38(1), 115-117. http://doi.org/10.1080/00036840500368094

Moravcová, E. (2014). Indikátory obav z kriminality v českých sociálněvědních výzkumech. Data a Výzkum, 8(2). http://doi.org/10.13060/23362391.2014.127.2.156

Pain, R. H. (1995). Elderly Women and Fear of Violent Crime: The Least Likely Victims?: A Reconsideration of the Extent and Nature of Risk. British Journal of Criminology, 35(4), 584-598.

Pechačová, Z., Hraba, J., Bao, W.-N., \& Lorenz, F. O. (1998). Pocit ohrožení kriminalitou v České republice/Perceived Risk of Crime in the Czech Republic. Sociologický časopis/Czech Sociological Review, 34(2), 205-219.

Peiró, A. (2006). Happiness, satisfaction and socio-economic conditions: Some international evidence. The Journal of Socio-Economics, 35(2), 348-365. http://doi.org/10.1016/j.socec.2005.11.042 
Powdthavee, N. (2005). Unhappiness and crime: Evidence from South Africa. Economica, 72(287), 531-547. http://doi.org/10.1111/j.0013-0427.2005.00429.x

Rountree, P. W., \& Land, K. C. (1996). Perceived Risk versus Fear of Crime: Empirical Evidence of Conceptually Distinct Reactions in Survey Data. Social Forces, 74(4), 1353-1376. http://doi.org/10.1093 /sf/74.4.1353

Russo, S., Roccato, M., \& Vieno, A. (2013). Criminal victimization and crime risk perception: A multilevel longitudinal study. Social Indicators Research, 112, 535-548. http://doi.org/10.1007/s11205-012 $-0050-8$

Ryan, R. M., \& Deci, E. L. (2001). On happiness and human potentials: A review of research on hedonic and eudaimonic well-being. Annual Review of Psychology, 52, 141-166. http://doi.org/10.1146/annurev.psych.52.1.141

Sacco, V. F. (1985). City size and perceptions of crime. Canadian Journal of Sociology/Cahiers Canadiens de Sociologie, 10(3), 277-293.

Sacco, V. F. (1990). Gender, fear, and victimization: A preliminary application of power-control theory. Sociological Spectrum, 10(4), 485-506. http://doi.org/10.1080/02732173.1990.9981942

Skogan, W. G., \& Maxfield, M. G. (1981). Coping with crime: Individual and neighborhood reactions. London: Sage.

Smith, L. N., \& Hill, G. D. (1991a). Perceptions of crime seriousness and fear of crime. Sociological Focus, 24(4), 315-327.

Smith, L. N., \& Hill, G. D. (1991b). Victimization and Fear of Crime. Criminal Justice and Behavior, 18(2), 217-239. http://doi.org/10.1177/0093854891018002009

Stack, S., \& Eshleman, J. R. (1998). Marital Status and Happiness: A 17-Nation Study. Journal of Marriage and the Family, 60(2), 527. http://doi.org/10.2307/353867

Staubli, S., Killias, M., \& Frey, B. S. (2014). Happiness and victimization: An empirical study for Switzerland. European Journal of Criminology, 11(1), 57-72. http://doi.org/10.1177/1477370813486866

Šolcová, I., \& Kebza, V. (2005). Prediktory osobní pohody (well-being) u reprezentativního souboru české populace. Československá Psychologie, 49(1), 1-8.

Tseloni, A., \& Zarafonitou, C. (2008). Fear of Crime and Victimization: A Multivariate Multilevel Analysis of Competing Measurements. European Journal of Criminology, 5(4), 387-409. http://doi .org/10.1177/1477370808095123

Tuček, M. (2013). Pocit bezpečí a spokojenost s činností policie - listopad 2013. Praha: Centrum pro výzkum veřejného mínění.

Visser, M., Scholte, M., \& Scheepers, P. (2013). Fear of Crime and Feelings of Unsafety in European Countries: Macro and Micro Explanations in Cross-National Perspective. The Sociological Quarterly, 54, 278-301.

Wanner, R. A., \& Caputo, T. C. (1987). Punitiveness, fear of crime, and perceptions of violence. Canadian Journal of Sociology/Cahiers Canadiens de Sociologie, 12(4), 331-344. http://doi.org/10.2307/3340941

Warr, M. (1984). Fear of Victimization: Why are Women and the Elderly More Afraid. Social Science Quarterly, 65(3), 681-702.

Warr, M. (2000). Fear of crime in the United States: Avenues for research and policy. Criminal Justice, 4(4), 451-489.

Weinrath, M., \& Gartrell, J. (1996). Victimization and fear of crime. Violence and Victims, 11(3), 187-197.

Williams, J. S., Singh, B. K., \& Singh, B. B. (1994). Urban youth, fear of crime, and resulting defensive actions. Adolescence, 29(114), 323-330.

Winkelmann, L., \& Winkelmann, R. (1998). Why are the unemployed so unhappy? Evidence from panel data. Economica, 65(257), 1-15.

Yin, P. P. (1980). Fear of Crime among the Elderly: Some Issues and Suggestions. Social Problems, 27(4), 492-504. http://doi.org/10.2307/800177

Zimmermann, A. C., \& Easterlin, R. A. (2006). Happily Ever After? Cohabitation, Marriage, Divorce, and Happiness in Germany. Population and Development Review, 32(3), 511-528. http://doi.org/10.1111 /j.1728-4457.2006.00135.x 